\title{
Photoperiodic control of sorus formation in the brown alga Laminaria saccharina
}

\author{
K. Lüning \\ Biologische Anstalt Helgoland, Notkestraße 31, D-2000 Hamburg 52, Federal Republic of Germany
}

\begin{abstract}
Adult sporophytes of Laminaria saccharina (L.) Lamour were collected near Helgoland, southern North Sea, and cultivated in an experimental tank system at each of 5 temperatures (range 2 to $20^{\circ} \mathrm{C}$ ) in short-day (SD; $8: \overline{16}$ ), long-day (LD; $16: \overline{8}$ ), and night-break (NB; $8: \overline{7.5}: 1: \overline{7.5}$ ) regimes (bar indicates hours of darkness). The seawater of the experimental tanks was mixed continuously. Sori were formed in $\mathrm{SD}$, but not in $\mathrm{LD}$ and NB. Optimal temperature range for sorus formation was 10 to $15^{\circ} \mathrm{C}$. In $\mathrm{SD}$, a period of retarded blade growth preceded sorus formation.
\end{abstract}

\section{INTRODUCTION}

Many Laminaria spp. exhibit a marked seasonal development, with maximum growth activity of the frond in the first half of the year, subsequent reduction of growth rates in summer, and formation of sori in autumn and winter, although there are species- and age-specific variations in this basic pattern (see review by Kain 1979). The search for possible environmental triggers has fascinated investigators since the beginning of this century.

The main question was: Which environmental factor(s) cause sporophytes of Laminaria spp. to reduce or even stop their growth activity in summer? Temperature, by causing supposedly high respiration rates in summer, cannot be a main factor in this respect, as shown by studies on annual carbon budgets of $L$. longicruris (Hatcher et al. 1977) and L. saccharina (Johnston et al. 1977): both species maintained a high net photosynthetic gain in summer (see discussion by Dring 1982). Furthermore, it was recently shown that $L$. saccharina in the laboratory has almost constant photosynthetic rates at growth temperatures between 5 and $20^{\circ} \mathrm{C}$ (Davison 1987, Davison \& Davison 1987).

There is the possibility that reduction of nutrient concentrations in seawater, mainly nitrate, is a major factor in summer reduction of laminarian growth rates in the field. Chapman \& Craigie (1977) succeeded in maintaining high spring growth rates until August in an experimental kelp bed of Laminaria longicruris by fertilizing it with $\mathrm{NaNO}_{3}$ from June onwards. Subse- quently, Conolly \& Drew (1985a,b) demonstrated that the late spring decline in growth rates of $L$. saccharina and $L$. digitata is due to depletion of nutrients in the seawater and can be halted by artificial fertilizing with nitrate and phosphate. However, Chapman \& Craigie (1977) also found that, even though fertilization with nitrate was continued until October, a decline in elongation rate in the plants occurred in September-October. They suggested that the decline was an effect of shortening daylength and, supposedly, depleted carbohydrate reserves.

Sorus formation is most frequent in autumn and winter in Laminaria saccharina (Parke 1948, Kain 1979, Lüning 1980), L. longicruris (Chapman 1973), and also in NW Pacific representatives of the Simplices group (e.g. L. angustata: Hasegawa 1962, Kawashima 1983; L. japonica: Funano 1980; L. religiosa: Abe et al. 1982). The question whether daylength per se, and/or temperature, might trigger this seasonal peak of sorus formation has rarely been examined experimentally. This is probably due to the fact that smaller algae were for technical reasons the prime candidates for detecting and analyzing first photoperiodic responses among algae (see review by Dring 1984).

The aims of the present investigation were (1) to develop an experimental tank system with continuous water mixing, and (2) to test for the presence of any effects of daylength and temperature on sorus formation and growth activity of sporophytes of Laminaria saccharina collected from the sea in late spring or summer. 


\section{MATERIALS AND METHODS}

Experimental tank system. The basic concept was to use pumps to continuously mix the seawater content of 20 experimental tanks ( 4 daylength regimes in each of 5 constant temperature rooms), in order to eliminate deviations in nutrient concentrations during long-term. culture of kelp sporophytes in different tanks and different constant temperature rooms (Fig. 1). Ca $4 \mathrm{~m}^{3}$ of seawater was available in the 20 experimental tanks. Continuous water mixing within constant temperature rooms (in $20 \mathrm{~min}$, see below) and between rooms (in 2 d) was performed by a total of 10 pumps.
In detail, each polyester seawater tank $(150 \times 50 \mathrm{~cm}$ $50 \mathrm{~cm}$ deep) was covered by a light-tight hood made of black PVC $(160 \times 60 \mathrm{~cm}, 60 \mathrm{~cm}$ high, $6 \mathrm{~mm}$ thick $)$, which had a sliding door $(120 \times 40 \mathrm{~cm})$ for insertion and removal of the experimental algae (Fig. 2). The algae were illuminated from above by 3 fluorescent lamps (Osram-L 65 W/25 S, Universal-White; photon fluence rate 30 to $60 \mu \mathrm{mol} \mathrm{m} \mathrm{m}^{-2} \mathrm{~s}^{-1}$, according to distance from water level; see Table 1). The lamps were contained within the light-tight hood, and the latter was equipped with a light-tight fan ensuring heat export from the lamps. Daylength regimes used were: short-day regime $(S D ; 8: \overline{16})$, long-day regime (LD;

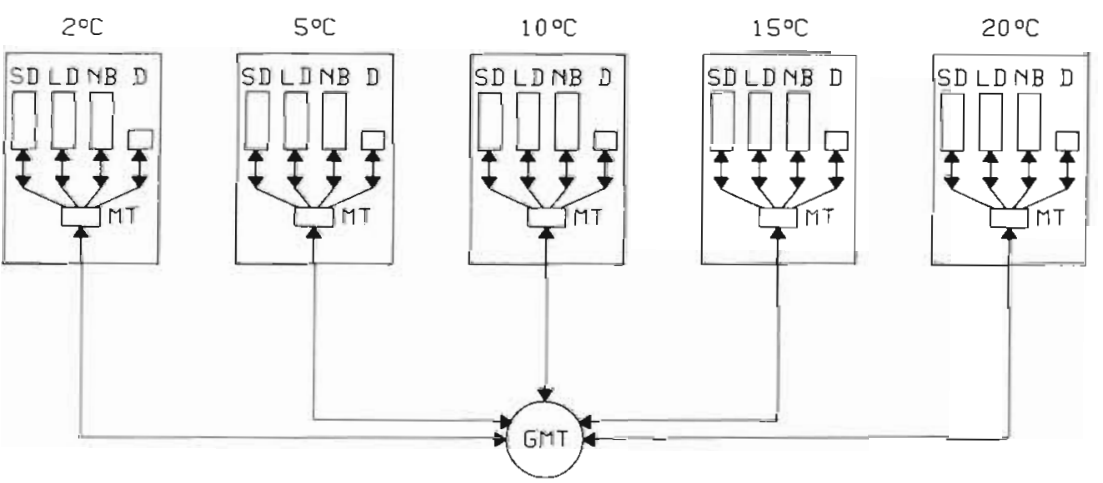

Fig. 1. Experimental tank system (not to scale), consisting of 4 tanks in each of 5 constant temperature rooms. SD: short-day regime $(8: \overline{16})$, LD: long-day regime $(16: \overline{8})$, NB: night-break regime $(8: \overline{7.5}: 1: \overline{7.5})$, D: continuous darkness (tank volume $40 \%$ of lit tanks). Ca $1 \mathrm{~m}^{3}$ of seawater is contained in each of the constant temperature rooms $\left(0.3 \mathrm{~m}^{3}\right.$ in each of the SD, LD. and NBtanks; $0.1 \mathrm{~m}^{3}$ in the $\mathrm{D}$ tank). MT: mixing tank within constant temperature room; GMT general mixing tank outside constant temperature room. Two pumps on top of each room mixing tank mix the seawater within each room in 20 min and between rooms in $2 \mathrm{~d}$. For the $20^{\circ} \mathrm{C}$ constant temperature room, tank volume for lit tanks was $80 \%$ of tank volume in other constant temperature rooms

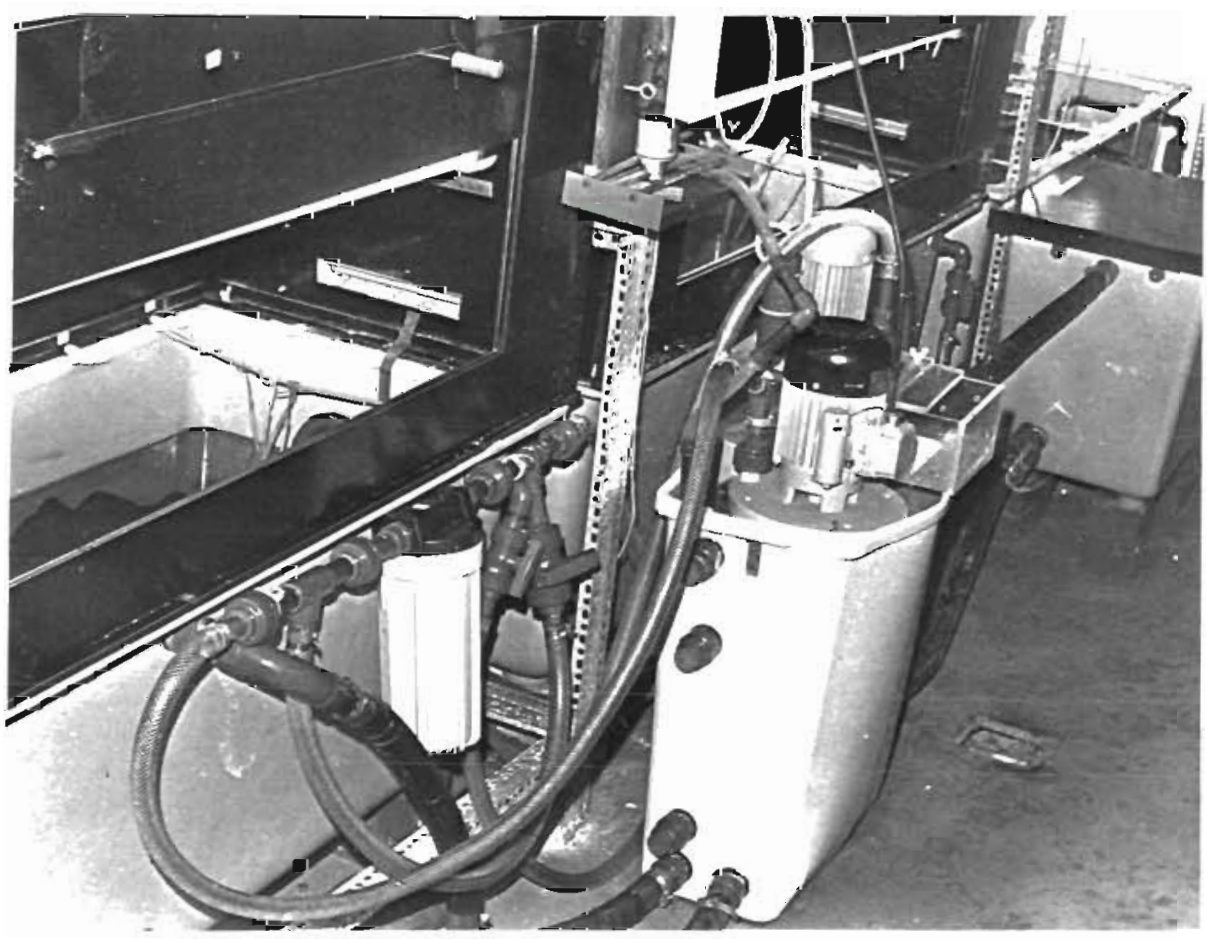

Fig. 2. Expenmental tank system; components in one of the constant temperature rooms: 2 tanks for $\mathrm{SD}$ and NB conditions (with lighttight hoods and slide doors), 1 tank for LD conditions (open to the room light), and 1 smaller tank for continuous darkness. Water from the 4 tanks enters the room mixing tank near its bottom; of the 2 pumps on top of the room mixing tank, the lower, larger pump transports water back into the tanks, the upper, smaller pump to the general mixing tank outside the constant temperature rooms. Upper middle: electric pinch valve controlling silicon tube for backflow of water from the general mixing tank 
Table 1. Laminaria saccharina. Sorus formation under different conditions of temperature and daylength. SD: short-day regime

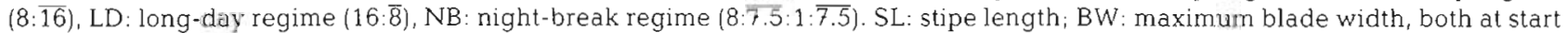
of experiment (numbers in brackets give confidence limits; $p=0.05$ ). Photon fluence rate at the algal level was $60 \mu \mathrm{mol} \mathrm{m} \mathrm{m}^{-2} \mathrm{~s}^{-1}$ in Expts 1 and 2, and $30 \mu \mathrm{mol} \mathrm{m} \mathrm{m}^{-2} \mathrm{~s}^{-1}$ in Expt 3. n: number of experimental plants in each condition (for LD and NB treatments in Expt $3, n=5$ ). - : No sorus formed at end of experiment. S: sorus formed; numbers in brackets give number of individuals with sorus followed by week at which sorus first became visible

\begin{tabular}{|c|c|c|c|c|c|c|}
\hline Expt & Experimental details & $n$ & $\begin{array}{l}\text { Temperature } \\
\qquad\left({ }^{\circ} \mathrm{C}\right)\end{array}$ & SD & LD & NB \\
\hline \multirow[t]{5}{*}{1} & 28 May-8 Sep 1986 (15 wk) & 1 & & & & \\
\hline & SL: $24 \pm 8 \mathrm{~cm} ; \mathrm{BW}:$ not measured & & 2 & - & - & - \\
\hline & & & 5 & - & - & - \\
\hline & & & 10 & S $(1$, Week 9$)$ & - & - \\
\hline & & & 15 & $\mathrm{~S}(1$, Week 12) & - & - \\
\hline \multirow[t]{5}{*}{2} & 2 Apr-22 Jul 1987 (16 wk) & 6 & & & & \\
\hline & $\mathrm{SL}: 17.5 \pm 1.0 \mathrm{~cm} ; \mathrm{BW}: 9.8 \pm 0.5 \mathrm{~cm}$ & & 3 & - & - & - \\
\hline & & & 8 & - & - & - \\
\hline & & & 12 & $\mathrm{~S}(2$, Week 10$)$ & - & - \\
\hline & & & 16 & $\mathrm{~S}(2$, Week 16) & - & - \\
\hline \multirow[t]{6}{*}{3} & 27 Jul-30 Sep 1987 (9 wk) & 6 & & & & \\
\hline & SL: $42.8 \pm 2.6 \mathrm{~cm} ; \mathrm{BW}: 8.0 \pm 0.5 \mathrm{~cm}$ & & 2 & - & - & - \\
\hline & & & 5 & $\mathrm{~S}(1$, Week 7$)$ & - & - \\
\hline & & & 10 & S $(6$, Week 6-7) & - & - \\
\hline & & & 15 & S $(6$, Week $6-7)$ & - & - \\
\hline & & & 20 & - & - & - \\
\hline
\end{tabular}

$16: \overline{8})$, night-break regime $(\mathrm{NB} ; 8: \overline{7.5} \cdot 1: \overline{7.5})$, (where bars indicate hours of darkness), and continuous darkness (only one experiment at one temperature performed). Seawater temperatures were kept constant $\left( \pm 0.5 \mathrm{C}^{\circ}\right)$.

Within each constant temperature room, the tanks were connected by flexible PVC tubes $(32 \mathrm{~mm}$ inner diameter) to a small room mixing tank $(50 \times 25 \mathrm{~cm}$, $60 \mathrm{~cm}$ deep) from which the water was pumped back into the 4 tanks by an immersion pump $(0.37 \mathrm{~kW})$ mounted on top of the room mixing tank (Fig. 2). Pumping rate was $50 \mathrm{l} \mathrm{min}^{-1}$, i.e. the ca $1 \mathrm{~m}^{3}$ of seawater contained in the 4 tanks in each constant temperature room was mixed within $20 \mathrm{~min}$. The immersion pump sucked the water from the upper $30 \mathrm{~cm}$ of the room mixing tank, and effected turbulence within the mixing tank as well as a water current (up to $1 \mathrm{~m} \mathrm{~s}^{-1}$ ) within the experimental tanks via a nozzle to which the water was re-distributed.

A second, smaller immersion pump, also mounted on top of each of the room mixing tanks, was triggered by an automatic time-switch to transport 201 of seawater $\mathrm{h}^{-1}\left(0.5 \mathrm{~m}^{3} \mathrm{~d}^{-1}\right)$ from each of the 5 constant temperature rooms to an overhead general mixing tank (100 l volume, $2.4 \mathrm{~m}$ above ground) outside the constant temperature rooms. After mixing of the incoming water by air bubbling for $10 \mathrm{~min}$, the water was able to flow back by gravity via silicon dispensing tubes into each of the room mixing tanks. An electric pinch valve was used to stop water back-flow via the silicon dispensing tubes during the mixing procedure. A daily export rate of $0.5 \mathrm{~m}^{3} \mathrm{~d}^{-1}$ from each constant temperature room means that the seawater contained in the 4 tanks of one constant temperature room would have appeared in the general mixing tank after $1.5 \mathrm{~d}$.

Algae and growth measurements. Sporophytes of Laminaria saccharina of similar size (blade length 1.5 to $2 \mathrm{~m}$ ) were collected by divers at 1 to 2 m below mean low water of spring tides in the sublittoral zone of Helgoland, North Sea. The algae were transported to Hamburg by ship in polyethylene barrels each filled with $30 \mathrm{l}$ of seawater. All experimental algae were cut to $1.5 \mathrm{~m}$ blade length (see Table 1 for further details), and a maximum of 6 individuals were placed in each tank. A hole (6 $\mathrm{mm}$ diameter) was punched at $10 \mathrm{~cm}$ from the junction between stipe and blade in each individual. The distance between the junction and the hole was measured once a week. At the end of each experiment, the algae were photographed on a light table

$\mathrm{N}$ and $\mathrm{P}$ additions, seawater replacement and epiphyte control. Seawater concentrations of nitrate and phosphate in the general mixing reservoir were determinated once a week according to the methods outlined in Grasshoff et al. (1983). $\mathrm{NaNO}_{3}$ and $\mathrm{KH}_{2} \mathrm{PO}_{4}$ from stock solutions were added to maintain concentrations of $40 \mu \mathrm{M} \mathrm{NO}_{3}^{-}$and $4 \mu \mathrm{M} \mathrm{PO}_{4}^{3-}$. After $1 \mathrm{wk}$, concentrations before nutrient addition had usually 
declined to $30( \pm 10) \mu M \mathrm{NO}_{3}^{-}$, and $3( \pm 2) \mu \mathrm{M} \mathrm{PO}_{4}^{3-}$ Nitrite concentrations were ca $0.2 \mu \mathrm{M} \mathrm{NO}_{2}^{-}$. No nutrients other than $N$ and $P$ were added. However, $2 \mathrm{~m}^{3}$ of the seawater of the experimental tank system was usually replaced each month from the institute's reservoir $\left(18 \mathrm{~m}^{3}\right)$ of seawater transported from Helgoland.

Three experiments were performed. Expt 1 (Table 1) was a pilot experiment with only 1 individual per experimental condition. Algae in this experiment experienced a changeable nutrient history, because different nutrient regimes were tried out, e.g. addition of nutrient enrichment, addition of $\mathrm{N}$ and $\mathrm{P}$ only, and no nutrient addition.

The seawater tanks and the experimental algae were cleaned every 2 to $3 \mathrm{wk}$ of epiphytic microalgae and of epiphytic smaller macroalgae such as Ectocarpus spp. Expt 3 had to be terminated 9 wk after start because of oil pollution of the seawater caused by a leaking pump condenser.

\section{RESULTS}

\section{Sorus formation}

All 3 experiments were started at a time of year when sori are absent on Laminaria saccharina near Helgoland, i.e. April to August. In September the first few sporogenous individuals are found, from October to January sori are common, and in February they become rare. As evident from Table 1 and Figs. 3 to 5, the formation of sori on plants in the experimental tanks occurred only in the SD regime, and was furthermore restricted to the upper temperature range, 10 to $15^{\circ} \mathrm{C}$ being optimal for sorus formation. At $5^{\circ} \mathrm{C}$ in $\mathrm{SD}$ (Expt 3), only 1 out of 5 individuals formed sori (Table 1). The NB regime prevented sorus formation in the same way as LD.

Expt 3 was started near the end of July, and all experimental algae became sporogenous at 10 and $15^{\circ} \mathrm{C}$ after about 1.5 mo in SD. Conversely, in Expt 2 , which was started in early April, only 2 out of 6 individuals formed sori under similar conditions, and this only after 3 to 4 mo (Table 1). During this long treatment the experimental sporophytes in SD and at higher temperatures began to lose progressively more of that distal tissue which one would have expected to produce the sorus and which was retained in the 2 individuals with sori (Fig. 4). Fortunately, Expt 1, i.e. the pilot experiment, was started sufficiently late in the year (end of May) to allow detection of the basic effect of sorus formation in SD and at higher temperatures, even with only one experimental alga per condition (Fig. 3)

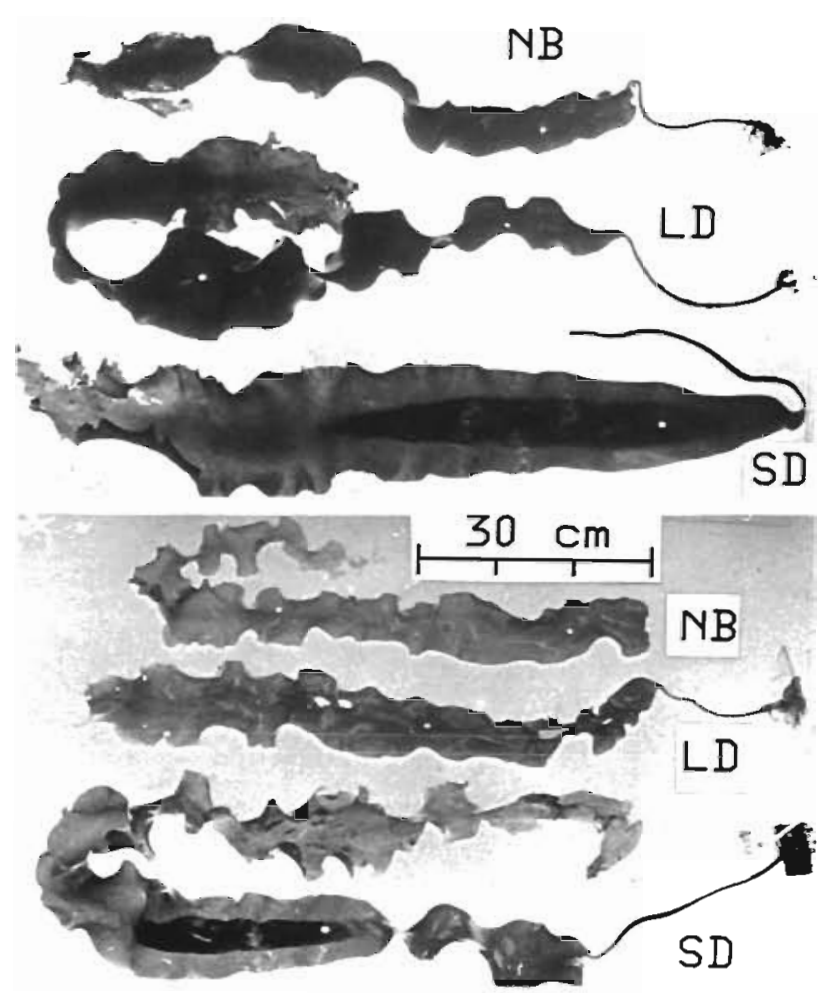

Fig. 3. Laminaria saccharina. Expt 1; started 28 May 1986; photographs taken on 8 Sep ( $15 \mathrm{wk}$ after start). Hole punched on 28 May at $10 \mathrm{~cm}$ distance from the junction between stipe and blade. Upper Individuals cultivated at $15^{\circ} \mathrm{C}$. NB individual: distal tissue lost which carried the hole of 28 May. Additional holes were punched in the NB and LD individuals on 20 Aug (12 wk after start). Lower: Individuals cultivated at $10^{\circ} \mathrm{C}$. NB individual: stipe lost in Week 8 . New hole punched on 20 Aug (12 wk after start). LD individual: temporary meristem damage at about $10 \mathrm{~cm}$ distance from the junction between stipe and blade (damage due to trapped air for a few days underneath the basal blade meristem). Sorus formation is visible in SD individuals as a black band

\section{Growth rate}

Growth rates of several $\mathrm{cm}$ per week were maintained in LD and NB conditions, whereas in SD little growth occurred, even long before the first sorus appeared (Fig. 6). For example, in Expt 3 (started at the end of July) about $20 \mathrm{~cm}$ of basal blade tissue were added in $9 \mathrm{wk}$ in $\mathrm{LD}$ and $\mathrm{NB}$ conditions at $10^{\circ} \mathrm{C}$, and only $3 \mathrm{~cm}$ in SD at the same temperature (Figs. 6 and 7 ). The reduced growth rate in the SD treatment was evident from the beginning in Expt 3 (Fig. 6). In spite of the substantial variability in individual growth rates the confidence bars given in Fig. 7 indicate that there are significant differences at 5 to $15^{\circ} \mathrm{C}$ between the $\mathrm{LD}$ and NB treatments on the one hand, and the SD treatment on the other hand in Expt 3 . Growth rates at $2^{\circ} \mathrm{C}$ were 


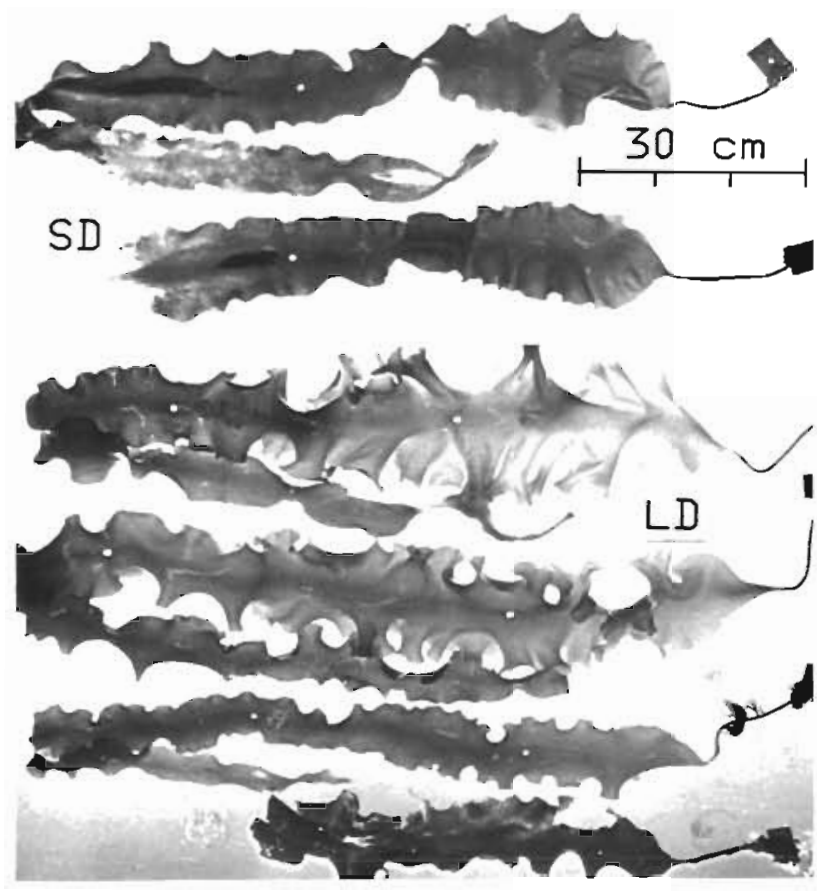

Fig. 4. Laminaria saccharina. Expt 2; started 2 Apr 1987; photographs taken on 16 Jun ( $11 \mathrm{wk}$ after start). Hole punched on $2 \mathrm{Apr}$ at $10 \mathrm{~cm}$ distance from the junction between stipe and blade. Upper: Individuals cultivated at $12^{\circ} \mathrm{C}, \mathrm{SD}$. Only the 2 individuals shown formed sori, visible as black bands. The other 4 individuals had lost distal tissue carrying the marking hole before sori were formed. Lower: Individuals cultivated at $12^{\circ} \mathrm{C}$, LD. Additional hole punched on 13 May $(6 \mathrm{wk}$ after start)

generally low and not significantly different between light regimes in Expt 3

Much higher growth rates were obtained in Expt 2 (started at the beginning of April) than in Expt 3 (started near the end of July). For instance, after 9 wk in the LD regime at medium temperatures, values of ca $60 \mathrm{~cm}$ growth were recorded in Expt 2 (Fig. 8), compared to ca $20 \mathrm{~cm}$ in Expt 3 (Figs. 6 and 7). In Expt 2, during which few individuals formed sori at all (see above), there were also high growth rates in SD (Fig. 8). Growth at $12^{\circ} \mathrm{C}$ was nevertheless significantly higher in $\mathrm{LD}$ than in $\mathrm{SD}$ conditions. These results may indicate that all plants grow about equally well as a function of daily irradiance (i.e. for comparison, multiply the rates for SD plants by a factor of 2).

One experiment in continuous darkness was performed. Experimental individuals of Laminaria saccharina collected from the sea in March (frond length 1 to $1.3 \mathrm{~m}$, new part of frond 7 to $9 \mathrm{~cm}$ wide) were subjected to continuous darkness at $3,8,12$, and $16^{\circ} \mathrm{C}$ $(n=5)$. After $3 w k$ there was an average increase in length of only $1.6,1.3,0.2$, or $1.0 \mathrm{~cm}$ respectively. After 3 mo of the dark treatment, all experimental individuals had decayed at $16^{\circ} \mathrm{C}, 4$ at $12^{\circ} \mathrm{C}, 4$ at $8^{\circ} \mathrm{C}$, whereas

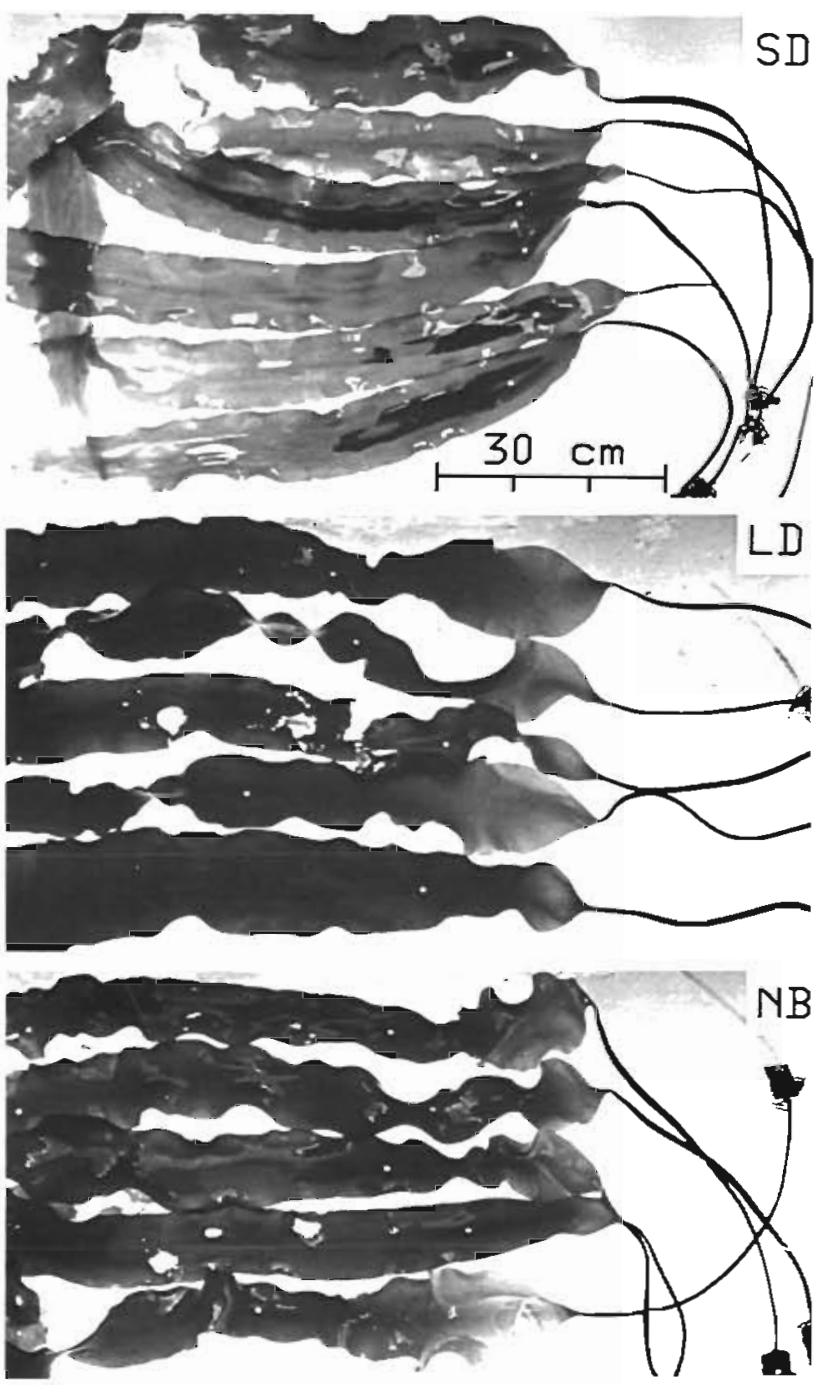

Fig. 5. Laminaria saccharina. Expt 3; started 27 Jul 1987; photographs taken on 2 Oct (9 wk after start). Individuals cultivated in $10^{\circ} \mathrm{C}$ and 3 daylength regimes. Hole punched on $27 \mathrm{Jul}$ at $10 \mathrm{~cm}$ distance from the junction between stipe and blade. Sorus has formed in SD treatment near marking hole and continues distally as a continuous black band. Other, isolated spots in all daylength regimes were present at the start of the experiment and possibly represent brown endophytes

all 5 experimental individuals had survived at $3^{\circ} \mathrm{C}$ $(3.2 \mathrm{~cm}$ length increase on average within $3 \mathrm{mo}$ ).

Stipe lengths did not significantly increase during the experiments (initial lengths are given in Table 1), nor did maximum blade width in Expt 3. Maximum blade width did increase, however, by several $\mathrm{cm}$ in Expt 2: on average by 8,10 , and $5 \mathrm{~cm}$ in LD at 3, 8, and $12^{\circ} \mathrm{C}$ respectively after $13 \mathrm{wk}$. The corresponding values for SD conditions were 6,5 , and $4 \mathrm{~cm}$ blade-width increase, and similar values, not significantly different from the SD values, were obtained for $\mathrm{NB}$. At $15^{\circ} \mathrm{C}$ in 


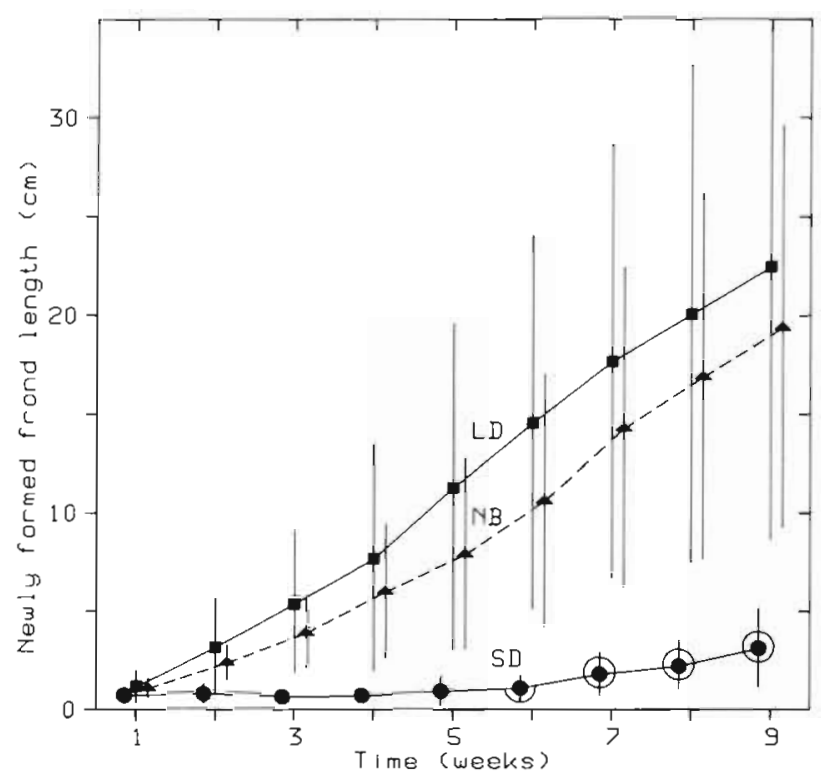

Fig. 6. Laminaria saccharina. Expt 3; started 27 Jul 1987. Cumulative elongation growth at $10^{\circ} \mathrm{C}$ and in 3 daylength regimes. Encircled points: all 6 individuals with sori; semiencircled points: 3 out of 6 individuals with sori. Photon fluence rate at algal level was $30 \mu \mathrm{mol} \mathrm{m} \mathrm{m}^{-2} \mathrm{~s}^{-1}$ Vertical bars are confidence limits $(p=0.05 ; n=6$ for $\mathrm{SD}, n=5$ for LD and $\mathrm{NB})$

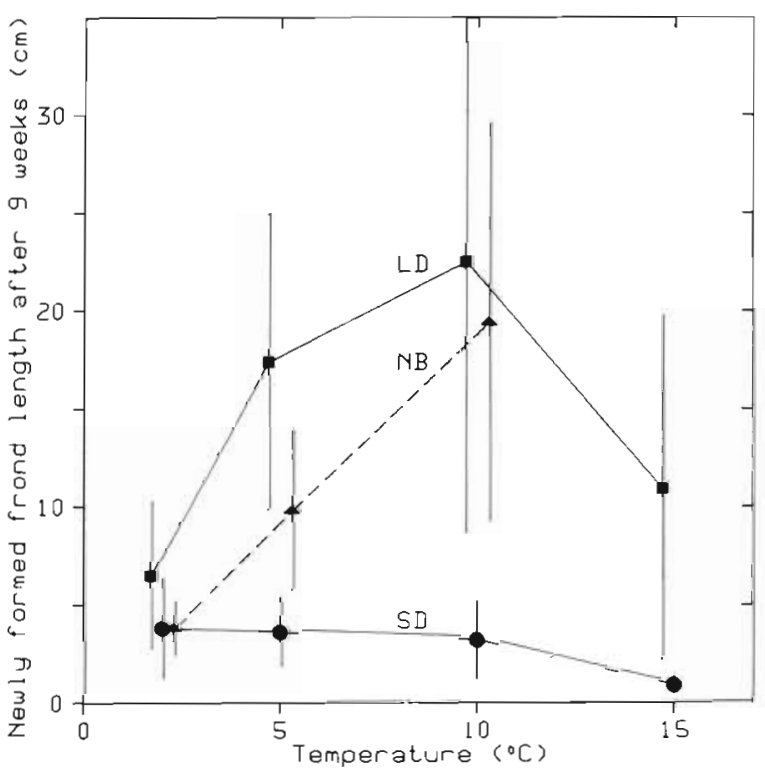

Fig. 7. Laminaria saccharina. Expt 3; started $27 \mathrm{Jul} 1987$ Elongation growth rates at $2,5,10,15^{\circ} \mathrm{C}$, and in 3 daylength regimes. NB treatment at $15^{\circ} \mathrm{C}$ was lost due to an experimental error. Photon fluence rate at algal level was $30 \mu \mathrm{mol}$ $\mathrm{m}^{-2} \mathrm{~s}^{-1}$. Vertical bars are confidence limits $(p=0.05 ; n=6$ for $\mathrm{SD} . n=5$ for LD and NB)

all 3 light-regimes, blade width in the new-grown blade tissue decreased by 3 to $4 \mathrm{~cm}$, and the experimental individuals were looking unhealthy, or had decayed after 13 wk.

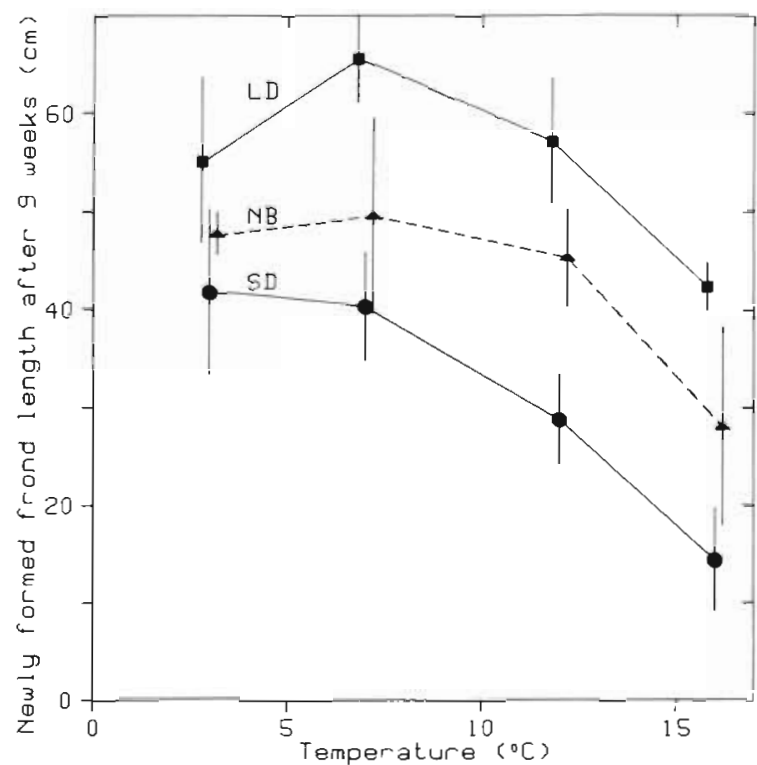

Fig. 8. Laminaria saccharina. Expt 2; started 2 Apr 1987 Elongation growth rates at $3,8,12,16^{\circ} \mathrm{C}$, and in 3 daylength regimes. Photon fluence rate at algal level was $60 \mu \mathrm{mol} \mathrm{m} \mathrm{m}^{-2}$ $s^{-1}$ Vertical bars are confidence limits $(p=0.05 ; n=6)$

\section{DISCUSSION}

The present results show that the SD light regime allows, and the LD and NB regimes prevent, sorus formation in Laminaria saccharina from Helgoland. Furthermore, a period of slow or even zero growth precedes sorus formation; this aspect will be discussed below. Another algal species is thus to be added to the steadily increasing list of genuine photoperiodic responses in algae (Dring 1984). Keath \& South (1985) drew attention to the sudden and synchronous formation of sori in Saccorhiza dermatodea at different depths and throughout the range of the species; they considered the possibility that a shortened daylength might trigger the reponse. Henry (1987) reported on a short-day effect on sorus formation in another member of the Laminariales, namely Phyllariopsis brevipes (= Phyllaria reniforme). Sporophytes of this species formed sori in the laboratory about 1 mo after transfer to short-day conditions, and long-day treatment (14 h light per day and more) prevented sorus formation.

The effect described here in Laminaria saccharina reveals an additional interesting ecological aspect, namely the restriction of sorus formation to SD conditions in the upper temperature range $\left(10\right.$ to $\left.15^{\circ} \mathrm{C}\right)$, i.e. discrimination of autumn conditions, although sorus formation is not entirely ruled out at $5^{\circ} \mathrm{C}$ (Table 1) Hence, the reaction may also enrich the list of algal responses which exhibit direct blocking by temperature at an optimal daylength (see Dring 1984 for discussion of 'seasonal windows' for reproduction) 
It should be kept in mind that the photoperiodic control of sorus formation reported here refers so far only to the geographical strain of Laminaria saccharina obtained from Helgoland. Future experiments must show whether L. saccharina has formed a geographical array of photoperiodic ecotypes differing in critical daylength, as in the small brown alga Scytosiphon lomentaria (Lüning 1980) and in the red alga Audouinella (= Rhodochorton) purpureum (Dring \& West 1983). Furthermore, daylength-neutral populations exist in S. lomentaria (e.g. Clayton 1978, Kristiansen \& Pedersen 1979, Correa et al. 1986, tom Dieck 1987). One has to test whether such a possibility might account for reports on the presence of sori in L. saccharina all year round, although with maximum sporogenesis between October and March (Devon and Argyll, UK; Parke 1948), or major sporogenesis peaks in October and June (Long Island, New York, USA; Lee \& Brinkhuis 1986). One should also test whether quantitative photoperiodic responses are involved, with short-day conditions not being essential but promoting sorus formation (Vince-Prue 1975).

An important factor influencing seasonal sorus occurrence may be age-class. This is shown by the following results reported by Hasegawa (1962) for Laminaria angustata, another member of the Simplices group, which attains a maximum age of 3 yr, like $L$. saccharina (Parke 1948). On the coast of Hidaka Province (Hokkaido, Japan), L. angustata becomes sporogenous in the first year from October onwards (at a minimum age of $8 \mathrm{mo}$ ), with sporogenesis peaking in January and finishing by the end of March. In the second year sori appear from July onwards; sporogenesis peaks in October and ends in February. In the third (last) year sporogenesis starts even earlier, by June, peaks again in October and ends in January. This pattern, with an earlier readiness for sorus formation after the first year of life, was substantiated again for L. angustata by Kawashima (1983), and for L. Saccharina by Parke (1948). The effect is paralleled by observations of a prolonged net growth season of blade tissue in first-year plants (e.g. Parke 1948, Lüning 1979), as recently evidenced by Druehl et al. (1987) for Laminaria groenlandica. An obvious shortcoming of the present investigation on $L$. saccharina is the unknown age of the experimental individuals. In view of the rather thick and long stipes (Figs. 3 to 5), however, and in comparison with stipe dimensions given by Parke (1948), and those observed by Lüning (1979) for first-year plants near Helgoland, it may be justified to estimate that individuals used were in their second or third year. One would thus expect an early readiness for sorus formation, and in the experiment started by the end of July (Expt 3) sori were in fact formed 6 to 7 wk after start of the SD treatment (Table 1).
The question why sporophytes subjected to SD conditions from April onwards (Expt 2; Table 1), did not form sori after $7 \mathrm{wk}$, but only after $10 \mathrm{wk}\left(12^{\circ} \mathrm{C}\right)$ or $16 \mathrm{wk}\left(16^{\circ} \mathrm{C}\right)$, and then only in a few cases, can at present only be a matter of speculation. One hypothesis might be that in the actively growing sporophytes collected from the sea in April the pathway leading to sorus formation is blocked internally due to high growth activity and externally by increasing daylength and low water temperature. The fact that 4 out of 6 individuals in Expt 2 had lost their distal tissue before it became competent for sorus formation may emphasize the more stressful conditions in the experimental tanks, compared to conditions in the sea, and point to the difficulty of experimenting with such large algae over longer periods with the limited amount of seawater in a laboratory. The somewhat labile and ephemerous appearance of the distal frond tissue in Laminaria saccharina may also be connected to the low capacity for dark growth from reserve materials stored in distal frond portions, as evidenced previously for this species by Dunton (1985) and confirmed in this investigation. This is in contrast to L. hyperborea, which forms an extensive new blade in darkness, and keeps an intactlooking distal old blade for a long time, also when kept in experimental tanks (Lüning 1986).

Finally, it seems worthwhile to ask: (1) Is growth reduction as observed in Laminaria saccharina in SD (Figs. 6 and 7 ) a by-product of sorus formation in such a way that the correlative inhibition of growth will end as soon as the reproductive step of sorus formation has been passed? If further experiments demonstrate that $L$. saccharina resumes growth after sorus formation in SD (as weakly suggested in Fig. 6), this possibility would be supported. Sanbonsuga \& Hasegawa (1969) observed that sporophytes of Costaria costata went through a period of retarded frond growth before sori appeared and that this reduction of growth rate did not occur in immature individuals growing in the same experimental tank. Research would thus move along a line shown by Lobban (1978) who emphasized that the growth of the Macrocystis sporophyte must be regulated both environmentally and internally, in analogy to higher plants. 'Fertility or its lack may be partly the result of a continuing influence of the apical meristem ... I suggest that the apical meristem leaves some inhibitor or repressor in the laminae that are to remain sterile... (Lobban 1978, p. 209). Or, (2) does growth reduction indicate the primary induction of a dormant state due to a daylength signal, while sorus formation is in parallel induced by the same environmental signal? In many higher plants autumnal short days induce and maintain growth suspension as one of the phenomena of dormancy, and one is able to obtain more or less indefinite growth in long-day conditions in certain species (e.g. 
Vince-Prue 1975, 1985). Conolly \& Drew (1985b) detected a dramatic enhancement of growth rate in midwinter in $L$. digitata and $L$. saccharina after transfer to long-day conditions. It is clear that further experiments are required before it can be established to what extent the seasonal development of laminarian species involves responses comparable to dormancy phenomena in higher plants.

Acknowledgements. I thank Petra Kadel, Hans Reichenberger, and Inka tom Dieck for valuable help and stimulating discussions.

\section{LITERATURE CITED}

Abe, E., Matsuyama, K., Tsuji, Y. (1982). On the recolonization of Laminaria religiosa Miyabe, in Oshoro Bay, Hokkaido. Sci. Rep. Hokk. Fish. Exp. Stat. 24: 41-50

Chapman, A. R. O. (1973). Phenetic variability of stipe morphology in relation to season, exposure, and depth in the non-digitate complex of Laminaria Lamour (Phaeophyta, Laminariales) in Nova Scotia. Phycologia 12: 53-57

Chapman, A. R. O., Craigie, J. S. (1977). Seasonal growth in Laminaria longicruris: relations with dissolved inorganic nutrients and internal reserves of nitrogen. Mar Biol. 40 197-205

Clayton, M. N. (1978). Morphological variation and life history in cylindrical forms of Scytosiphon lomentaria (Scytosiphonaceae: Phaeophyta) from southern Australia. Mar Biol. 47: 349-357

Conolly, N. J., Drew, E. A. (1985a). Physiology of Laminaria. III. Effect of a coastal eutrophication gradient on seasonal patterns of growth and tissue composition in $L$. digitata Lamour and L. saccharina (L.) Lamour. P.S.Z.N.I. Mar. Ecol. 6: 181-195

Conolly, N. J., Drew, E. A. (1985b). Physiology of Laminaria. IV Nutrient supply and daylength, major factors affecting growth of $L$. digitata and $L$. saccharina. P.S.Z.N.I. Mar. Ecol. 6: 299-320

Correa, J., Novaczek, I., McLachlan, J. (1986). Effect of temperature and daylength on morphogenesis of Scytosiphon lomentaria (Scytosiphonales, Phaeophyta) from eastern Canada. Phycologia 25: 469-475

Davison, I. R. (1987). Adaptation of photosynthesis in Laminaria saccharina (Phaeophyta) to changes in growth temperature. J. Phycol. 23: 273-283

Davison, I. R., Davison, J. O. (1987). The effect of growth temperature on enzyme activities in the brown alga Laminaria saccharina. Br. phycol. J. 22: 273-283

Dieck, I. tom (1987). Temperature tolerance and daylength effects of isolates of Scytosiphon lomentaria (Scytosiphonales, Phaeophyceae) of the North Atlantic and Pacific Ocean. Helgoländer Meeresunters. 41: 307-321

Dring. M. J. (1982). The biology of marine plants. Edward Arnold, London

Dring, M. J. (1984). Photoperiodism and phycology. Prog. phycol. Res. 3: 159-162

Dring, M. J., West, J. A. (1983). Photoperiodic control of tetrasporangium formation in the red alga Rhodochorton purpureum. Planta 1.59: 143-1.50

Druehi, L. D., Cabot, E. L., Lloyd, K. E. (1987). Seasonal growth of Laminaria groenlandica as a function of plant age. Can. J. Bot. 65: 1599-1604
Dunton, K. H. (1985). Growth of dark-exposed Laminaria saccharina (L.) Lamour. and Laminaria solidungula J. Ag. (Laminariales: Phaeophyta) in the Alaskan Beaufort Sea. J. exp. mar. Biol. Ecol. 94: 181-189

Funano, T (1980). Ecological and maricultural studies on Laminaria japonica growing on the shores of Date City, Hokkaido. I. Ecology of L. japonica. Scl. Rep. Hokkaido Fish. Exp. Stat. 22: 17-77

Grasshoff, K., Ehrhardt, M., Kremling, K. (1983). Methods of seawater analysis, 2nd edn. Verlag Chemie, Weinheim

Hasegawa. Y. (1962). An ecological study of Laminaria angustata Kjellman on the coast of Hidaka Prov., Hokkaido. Bull. Hokkaido reg. Fish. Lab. 24: 116-138

Hatcher, B. G., Chapman, A. R. O., Mann, K. H. (1977). An annual carbon budget for the kelp Laminaria longicruris. Mar. Biol. 44: 85-96

Henry, E. C. (1987). The life history of Phyllariopsis brevipes (= Phyllaria reniforme) (Phyllariaceae, Laminariales, Phaeophyceae), a kelp with dioecious but sexually monomorphic gametophytes. Phycologia 26: 17-22

Johnston, C. S., Jones, R. G., Bunt, R. D. (1977). A seasonal carbon budget for a laminarian population in a Scottish sea-loch. Helgoländer wiss. Meeresunters. 30: 527-545

Kain, J. M. (Mrs N. S. Jones) (1979). A view of the genus Laminaria. Oceanogr. mar. Biol. A. Rev. 17: 101-161

Keath, D. W., South, G. R. (1985). Aspects of reproductive phenology of Saccorhiza dermatodea (Phaeophyta, Laminariales) in Newfoundland. Br. phycol. J. 20: 117-122

Kawashima, S. (1983). Sporangial sorus formation of Laminaria angustata Kjellman. Jap. J. Phycol. 31: 208-216

Kristiansen, A., Pedersen, P. M. (1979). Studies on life history and seasonal variation of Scytosiphon lomentaria (Fucophyceae, Scytosiphonales) in Denmark. Bot. Tidskr. 74: 31-56

Lee, J.-A., Brinkhuis, B. H. (1986). Reproductive phenology of Laminaria sacchanina (L.) Lamour. (Phaeophyta) at the southern limit of its distribution in the northwestern Atlantic Ocean. J. Phycol. 22: 276-285

Lobban, C. S. (1978). The growth and death of the Macrocystis sporophyte (Phaeophyceae, Laminariales). Phycologia 17: 196-212

Lüning, K. (1979). Growth strategies of three Laminaria species (Phaeophyceae) inhabiting different depth zones in the sublittoral region of Helgoland (North Sea). Mar. Ecol. Prog. Ser. 1: 195-207

Lüning, K. (1980). Control of algal life-history by daylength and temperature. In: Price, J. H. Irvine, D. E. G., Farnham, W. F. (ed.) The shore environment, Vol. 2, Ecosystems Academic Press, p. 915-945

Lüning, K. (1986). New frond formation in Laminaria hyperborea (Phaeophyta): a photoperiodic response. $\mathrm{Br}$. phycol J. $21.269-273$

Parke, M. (1948). Studies on British Laminariaceae. I. Growth in Laminaria saccharina (L.) Lamour. J. mar. biol. Ass. U. K. 27: $651-709$

Sanbonsuga, Y., Hasegawa, Y (1969). Studies on Lamınariales in culture. II. Effects of culture conditions on the zoosporangium formation in Costaria costata (Turn.) Saunders. Bull. Hokkaido reg. Fish. Lab. 35: 198-202

Vince-Prue, D. (1975). Photoperiodism in piants. McGrawHill, London

Vince-Prue, D. (1985). Photoperiodism and hormones. In Pharis, R. P., Reid, D. M. (ed.) Encyclopedia of plant physiology, new series, Vol. 11B. Hormonal regulation of development, III, Role of environmental factors. SpringerVerlag, BerIin, Heidelberg, p. 308-364 